\title{
Dietary composition and trophic level of Hypanus marianae (Myliobatiformes: Dasyatidae), captured off Pernambuco coast, Brazil
}

\author{
Aristóteles P.N. Queiroz ${ }^{1,2}$, Maria L.G. Araújo ${ }^{3}$ \& Rosângela P.T. Lessa ${ }^{1,2}$ \\ ${ }^{1}$ Universidade Federal de Pernambuco, Programa de Pós-graduação em Biologia Animal, Recife, Brasil \\ ${ }^{2}$ Laboratório de Dinâmica de Populações Marinhas-DIMAR, Departamento de Pesca e Aquicultura \\ Universidade Federal Rural de Pernambuco, Recife, Brazil \\ ${ }^{3}$ Departamento de Pesca e Aquicultura, Universidade Federal de Sergipe, São Cristóvão Sergipe, Brasil \\ Corresponding author: Aristóteles P.N. Queiroz (queirozapn@ gmail.com)
}

\begin{abstract}
Hypanus marianae, a stingray endemic to Brazil, inhabits coastal coral reef areas occurring in the landings of artisanal fisheries. The present study aimed to characterize the diet of this species captured off Pernambuco. We obtained 77 stomachs with contents: $52.27 \%$ female, $47.72 \%$ male. DW ranged from 15 to $37.80 \mathrm{~cm}$ mean of $26.53 \pm 4.82 \mathrm{~cm}$. Four higher taxonomic prey categories were identified: Arthropoda, Annelida, Chordata and Sipuncula. The most important item in the diet was Polychaeta (40.65\% IRI), followed by Leptochela serratorbita (30.35\% IRI), suborder Dendrobranchiata (10.18\% IRI), order Isopoda (4.19\% IRI), and Meiosquilla schmitti (3.56\% IRI). H. marianae displays specialized predatory habit $\left(\mathrm{B}_{\mathrm{A}}=0.06\right)$ primarily based on shrimps (42.36\% IRI) and polychaetes (40.65\% IRI). There was no significant difference in the diet by sex or in sexual development stages. However, neonates fed on decapods crustaceans $(70.68 \%)$ and polychaetes (17.09\%). For immatures, decapod crustaceans $(69.5 \%)$ and polychaetes $(25.86 \%)$ made up most of their diet. The adults feed mainly on polychaetes $(62.79 \%)$ and crustacean decapods $(30.47 \%)$, with a slight increase of fish (5.46\%). The trophic level (TL) estimated was based on stomach content analysis was 3.66 and estimated on the analysis of stable isotopes being 3.29, which classified the species as a mesopredator.
\end{abstract}

Keywords: Dasyatis marianae; elasmobranchs; endemic ray; trophic ecology; South America

\section{INTRODUCTION}

In tropical regions, the most numerous groups of Batoidea are the Myliobatiformes (Ebert \& Compagno, 2007; Aschliman et al., 2012). The rays of the Myliobatiformes order account for $43 \%$ of all batoids and for more than $22 \%$ of all known species of Chondrichthyes (Ebert \& Compagno, 2007; Weigmann, 2016).

In Brazil, out of 26 species of the Myliobatiformes order (Rosa \& Gadig, 2014), seven species of the Dasyatidae family occupy coastal and estuarine environments (Bigelow \& Schroeder, 1953; McEachran $\&$ Carvalho, 2002; Santos \& Carvalho, 2007). Hypanus marianae (Gomes, Rosa \& Gadig, 2000) is endemic to coastal areas of northeastern Brazil (Bender et al., 2013;
Costa et al., 2017), occurring in artisanal fisheries (Yokota \& Lessa, 2007) where it is locally named "bigeye-stingray" or "coã-stingray".

Adult specimens of big-eye-stingray occupy coral reef areas, with seagrass beds as the preferred habitat of females, while immature stingrays concentrate on sandy bottoms, near the beach and on sandbanks (Gomes et al., 2000; Costa et al., 2015). Coastal sandbanks are likely the primary nursery areas for this species (Yokota \& Lessa, 2006).

The feeding biology of elasmobranchs have been investigated in the last decade in order to describe the diet of the species (Wetherbee \& Cortés, 2004; Navia et al., 2007; Albo-Puigserver et al., 2015; López et al., 2016; Wilga et al., 2016); to understand the role of given species in marine ecosystems (Wetherbee \& 
Cortés, 2004; Navia et al., 2007; Albo-Puigserver et al., 2015; Madigan et al., 2015; López et al., 2016); to estimate predation impacts on economically valuable or threatened species (Myers et al., 2007) as well as to elucidate the biomechanic processes involved in predation strategies (Dean et al., 2005; Wilga et al., 2016). However, studies on the feeding biology of elasmobranchs are more frequently focused on shark species.

Quantitative studies on Dasyatidae stingrays' diet and trophic ecology being scarce (Aguiar \& Valentin, 2010; Shibuya \& Rosa, 2011) though, this researches may contribute to a better understanding of the mesopredators' role and can help in the development of ecosystem-based management approaches (Heithaus et al., 2008; Rocchi et al., 2017), as this information increases the understanding of the fishing impacts on mesopredator species (Grubbs et al., 2016).

The combination of traits such as endemism, small body and feeding of invertebrates, may drive $H$. marianae to a high-risk probability of extinction (Bender et al., 2013) since its preferred habitats are highly sensitive to environmental changes. In IUCN assessments, H. marianae is classified as DD (Data Deficient) due to the lack of information necessary to adequately assess its extinction risk (Rosa \& Furtado, 2016). Thus, the objective of the current study is to analyze the diet and to verify the occurrence, or not, of sexual and ontogenetic changes in $H$. marianae, landed along the Pernambuco coast. Furthermore, the trophic level of the species will be inferred through the stomach contents and stable isotope analysis.

\section{MATERIALS AND METHODS}

\section{Sample collection}

The specimens of Hypanus marianae were obtained from artisanal fisheries off Pernambuco coast, Brazil (7³7'33.6”'S, $34^{\circ} 48^{\prime} 52.4^{\prime \prime} \mathrm{W}$ to $8^{\circ} 53^{\prime} 19.0^{\prime \prime} \mathrm{S}$, $\left.35^{\circ} 08^{\prime} 59.8^{\prime \prime} \mathrm{W}\right)$. The sample sites were Ponta de Pedras (PP), Itamaracá (IT), Sirinhaém (SI) and São José da Coroa Grande (SJ), where the individuals are captured as bycatch in fish-weirs, in beach seine, shrimp trawl and longline, respectively (Fig. 1).

After sampling, the specimens were sexed, photographed and weighed (in g). The disc width (DW) was measured (in $\mathrm{cm}$ ), and the sexual development stages were determined by macroscopic analysis of the reproductive organs, according to the criteria established by ICES (2012).

The stomachs were removed and then stored in $4 \%$ formalin solution. After $48 \mathrm{~h}$, the stomachs were excised, washed with tap water and the food contents were



Figure 1. Locations of landings of Hypanus marianae in Pernambuco, Brazil, in Ponta de Pedras (PP), Itamaracá (IT), Sirinhaém (SI) and São José da Coroa Grande (SJ) from July 2013 to October 2016.

retained in a sieve mesh of $0.1 \mathrm{~cm}$ and preserved in $70^{\circ} \mathrm{GL}$ ethanol. The material was analyzed under a stereoscopic microscope, and food components were identified to the lowest possible taxonomic level. After, the items were separated, counted, and individually weighed to the nearest $0.0001 \mathrm{~g}$ (Cortés, 1997). The excess ethanol was removed with a paper towel (Magnusson et al., 2003; Aguiar, 2010).

Algae and sediment were considered accidental ingestions and thus were excluded from the analysis (as well as all unrecognized materials). Stomachs showing only unidentifiable material were treated as empty stomachs and were excluded from the analysis.

\section{Quantitative analysis of diet}

A prey accumulation curve (Cortés, 1997) was built using Estimate ${ }^{\odot}$ version 7.5.1 to verify whether the number of analyzed stomachs was sufficient to represent the species diet, based on the reduction of standard deviations. Thus, the percentage frequency of occurrence $(\mathrm{O} \%)$, the numerical occurrence or number percentage $(\mathrm{N} \%)$ and weight $(\mathrm{W} \%)$ were calculated. The index of relative importance (IRI) was determined according to Pinkas et al. (1971), and also calculated as 
a percentage $(\%$ IRI $)($ Cortés, 1997): \%IRI = (IRI / $\sum$ IRI) $\times 100$.

The diet niche breadth was estimated using Levin's index $\mathrm{Bi}$ (Krebs, 1999): $\mathrm{Bi}=1 / \sum \mathrm{P}_{\mathrm{j}}{ }^{2}$, where $\mathrm{P}_{\mathrm{j}}$ is the fraction by IRI of each food $\mathrm{j}$ in the diet. The values were standardized for $\mathrm{B}_{\mathrm{A}}$ (Krebs, 1999): $\mathrm{B}_{\mathrm{A}}=(\mathrm{Bi}-1)$ / $(\mathrm{N}-1)$, where $\mathrm{N}$ is the number of classes, and $\mathrm{B}_{\mathrm{A}}$ ranges from 0 to 1 . Low values of $B_{A}$ indicate diets dominated by few prey items (specialist predators), while higher values indicate generalist diets.

The trophic level (TL) of the species, based on stomach contents, was also calculated (Cortés, 1999): $\mathrm{TL}_{\mathrm{k}}=1+\left(\sum_{j=1}^{n} P_{j} \times T L_{\mathrm{J}}\right)$, where $\mathrm{TL}_{\mathrm{k}}$ is the trophic level of the species $(\mathrm{k}), \mathrm{P}_{\mathrm{j}}$ is the proportion of the prey category $(j)$ in predator diet $(k)$; $n$ is the total number of prey categories, and $\mathrm{TL}_{\mathrm{j}}$ is the trophic level of the prey group (j). We used the trophic level values of the prey categories suggested by Ebert \& Bizzarro (2007) for trophic level analysis in batoids.

The weight data of the food items were grouped into five categories of prey, suggested by Ebert \& Bizzarro (2007): decapods (crustacean decapods); fishes (fish teleost); amphipods (amphipods and isopods); polychaetes (polychaetes worms) and other crustaceans (crustaceans not included in the decapod order).

Based on the weight of each prey category, the data of food items were transformed in square-root, and a Bray-Curtis similarity coefficient was used to construct a similarity matrix (Jacobsen \& Bennet, 2012).

The one-way similarity analysis (ANOSIM) using the similarity matrix, was conducted considering individuals as samples and sex and sexual development stages as factors. The R-value resulted by the ANOSIM analysis (the strength of the factors on the samples) and the significance level $(P)$ was evaluated using a random permutation test with 999 permutations (Clarke \& Gorley, 2006). When $\mathrm{R}=0$, there are no differences among the groups (sex and sexual development stages) or the samples (stomach) in each group. When $\mathrm{R}=1$, the samples of the groups are similar, but the groups are different. Statistical significance was set at $P<0.05$. Diet similarity was also analyzed by non-metric multidimensional scaling analysis (nMDS).

Finally, the percentage of similarity (SIMPER) was used to estimate the contribution of each prey category to the diet of each factor (sex or sexual development stages). The analyses were performed using the software Primer v.6 (Clarke \& Gorley, 2006).

\section{Muscle tissue collection}

Muscle samples of $H$. marianae were obtained from eight individuals, taken from the lower portion of the pectoral fin and stored frozen. As stipulated by Post
(2002), muscle tissue samples from an herbivorous species were obtained $(n=2)$ to be used as a baseline. The species chosen were the teleost fish Sparisoma axillare (Steindachner, 1878), an herbivore (Rosa \& Moura, 1997) that occurs in the same coral reef environment as $H$. marianae, which reflects the $\delta^{15} \mathrm{~N}$ and $\delta^{13} \mathrm{C}$ value of the base of the food chain (Post, 2002).

\section{Stable isotope analysis}

The collected material was cut in $1 \mathrm{~cm}^{2}$ cubes and placed in test tubes, following the methodology suggested by Kim \& Koch (2012) for extraction of lipids from the tissue by the addition of $10 \mathrm{~mL}$ of petroleum ether. The test tubes were then shaken in Ultrasonic Washer (Ultracleaner 700 - Unique) for 15 $\mathrm{min}$. The petroleum ether solution was discarded, and the procedure repeated. After, $10 \mathrm{~mL}$ of deionized water was added to extract the urea accumulated in the tissue; the test tube was stirred for $15 \mathrm{~min}$, and then the deionized water solution was discarded and the process repeated twice.

After the extraction of lipids and urea, H. marianae muscle tissue samples were lyophilized. Finally, the material was macerated and subjected to stable isotope analysis on a mass spectrometer.

The values of $\delta$ were calculated from the reference standards of carbon (Pee Dee Belemnite) and nitrogen (atmospheric air), according to equation (Peterson \& Fry, 1987):

$$
\delta_{\text {sample }}=\left[\left(\frac{R_{\text {sample }}}{R_{\text {standard }}}\right)-1 \times 1,000\right],
$$

where $\mathrm{R}$ represents the ratio of the heaviest to the lightest isotope $\left({ }^{15} \mathrm{~N}:{ }^{14} \mathrm{~N} ;{ }^{13} \mathrm{C}:{ }^{12} \mathrm{C}\right)$.

\section{Trophic level estimate}

The trophic level of the species was calculated using the formula described by Post (2002):

$$
\mathrm{TL}_{\delta^{15} \mathrm{~N}}=\mathrm{TL}_{\text {baseline }}+\frac{\left(\delta^{15} \mathrm{~N}_{\text {predator }}-\delta^{15} \mathrm{~N}_{\text {baseline }}\right)}{1.5 \% 0},
$$

where $\mathrm{TL}_{\delta^{15} \mathrm{~N}}$ is the trophic position of the predator, $\mathrm{TL}_{\text {baseline }}$ is the trophic position of the baseline $\left(\mathrm{TL}_{\text {baseline }}\right.$ $=2), \delta^{15} \mathrm{~N}_{\text {predator }}$ is the $\delta^{15} \mathrm{~N}$ value of the consumer, $\delta^{15} \mathrm{~N}_{\text {baseline }}$ is the $\delta^{15} \mathrm{~N}$ value of the baseline and $1.5 \%$ is the expected enrichment in $\delta^{15} \mathrm{~N}$ per trophic level.

The enrichment constant of $\delta^{15} \mathrm{~N}$ used was based on a study by Galván et al. (2016), which estimated the trophic discrimination factors (TDF) and turnover rates in blood and muscle of the small nose fanskate Sympterygia bonapartii (Müller \& Henle, 1841) through controlled feeding. The results found by Galván et al. (2016) led to an estimated TDF value for $S$. bonapartii of $1.5 \%$. Since the enrichment constant 
may vary according to the species studied (Post, 2002; Hussey et al., 2014), the estimated value for $S$. bonapartii was used because it lives in a benthic habitat similar that of $H$. marianae.

\section{RESULTS}

Out of 89 of Hypanus marianae specimens, 77 had a disc width (DW) of 15 to $37.80 \mathrm{~cm}$ (mean $26.53 \pm 4.82$ $\mathrm{cm})$ and had identifiable stomach contents. Females represented $52.27 \%$ (15 to $37.80 \mathrm{~cm} \mathrm{DW}$ ) and males $47.72 \%$ (15.10 to $30.7 \mathrm{~cm} \mathrm{DW}$ ) of the total sample. The prey accumulation curve tends to an asymptote in the last five points of the curve (Fig. 2), meaning that the sample size was sufficient to represent the diet of the species.

The four most frequent prey categories identified in this study were Arthropoda (Amphipoda, Decapoda, Isopoda and Stomatopoda); Annelida (Polychaeta); Chordata (Teleostei) and Sipuncula (Table 1).

The most important item in $H$. marianae diet was the class Polychaeta (40.65\% IRI), followed by Leptochela serratorbita (Spen Bate, 1888) (30.35\% IRI), suborder Dendrobranchiata (10.18\% IRI), order Isopoda (4.19\% IRI), and Meiosquilla schmitti (Schmitt, 1940) (3.56\% IRI) (Table 1).

The similarity analysis (ANOSIM) indicated no significant differences in feeding between the sexes (Global R $=0.04 ; P=0.09$ ) or in relation to sexual development stages (Global $\mathrm{R}=0.02 ; P=0.23$ ). Results were also corroborated using non-metric multidimensional scaling analysis (nMDS), which revealed overlap in diet between the sexes and among the sexual development stages (Fig. 3).

$H$. marianae showed low value in diet breadth based on Levin's index $\left(B_{A}=0.06\right)$. Data showed a specialist feeding strategy, with a diet primarily based on shrimps (suborder Dendrobranchiata, family Sergestoidea, Rimapenaeus constrictus (Stimpson, 1871), Leptochela serratorbita (Spence Bate, 1888), Sicyonia parri (Burkenroad, 1934) and Pleoticus muelleri (Spence Bate, 1888)) with $42.36 \%$, of IRI and polychaetes (40.65\% IRI) (Table 1). Results corroborate with the similarity percentage analysis (SIMPER), which showed prey categories that most contributed to the diet of all groups (Table 2).

Neonates (young of the year) of $H$. marianae displayed a diet based on decapod crustaceans, polychaetes, and amphipods, whereas immature individuals displayed a diet mostly of decapod crustaceans and polychaetes. Similarly, the adults fed mainly on polychaetes, decapod crustaceans and fish (Table 2). Teleostei fish were found in seven examined stomachs,

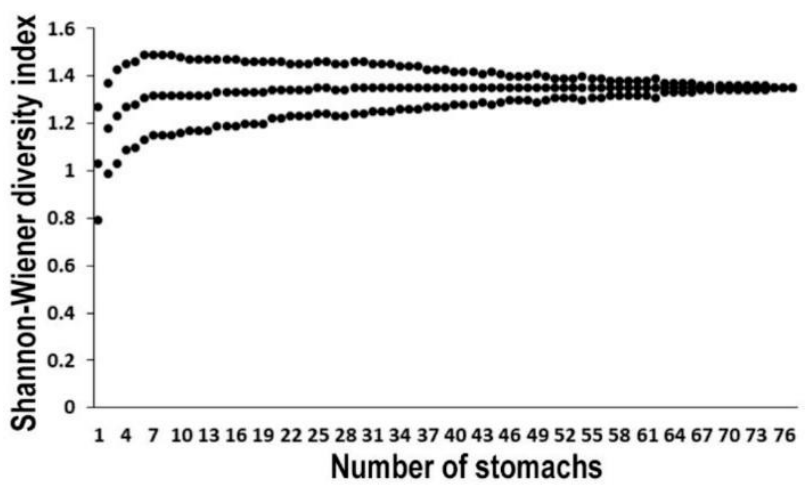

Figure 2. Cumulative average and standard deviation of the Shannon-Wiener diversity index of food items in the stomachs of Hypanus marianae off Pernambuco coast, Brazil from July 2013 to October 2016.

two adult males and five adult females; one was pregnant.

The trophic level (TL) estimated for H. marianae based on stomach content analysis was 3.66. The mean $\delta^{15} \mathrm{~N}$ value was $11.68 \pm 0.92$, and the estimated TL was $3.29 \pm 0.61$ (Table 3 ).

\section{DISCUSSION}

The cumulative prey curve for Hypanus marianae tended to an asymptote in 72 stomachs, more than twice the value found by Costa et al. (2015), in samples from the state of Rio Grande do Norte, whose asymptote was reached at 31 stomachs, probably because in this work almost twice as many food items were identified, compared to Costa et al. (2015). The early stabilization of the curve is justified by the small niche breadth found for $H$. marianae $\left(\mathrm{B}_{\mathrm{A}}=0.06\right)$, indicating a reduced diversity of food items in the diet, which is typical of specialized diets, as is the case for Rhinobatos percellens from southern Brazil (Levin's index $\mathrm{B}_{\mathrm{A}}=$ 0.06) (Carmo et al., 2015).

H. marianae is associated with coral reefs (Gomes et al., 2000; Costa et al., 2015, 2017), reflecting a feeding strategy based on the predation of benthic reef organisms, such as small crustaceans and polychaetes. Similarly, in Australia and the Caribbean, the diets of Pastinachus ater, Himantura uarnak, Neotrygon kuhlii, Taeniura lymma, Urogymnus asperrimus (O'Shea et al., 2013) and Hypanus americanus are predominantly made up of polychaetes and shrimp (Tilley et al., 2013).

Although polychaetes have been a significant item in the diet of $H$. marianae, accounting for $40.65 \%$ of the IRI, shrimp (suborder Dendrobranchiata, family Sergestoidae, Rimapenaeus constrictus, Leptochela serratorbita, Sicyonia parri and Pleoticus muelleri) corresponded to $42.36 \%$ of IRI. Some other batoid from 
Table 1. Occurrence $(\mathrm{O})$, frequency of occurrence $(\mathrm{FO} \%)$, number $(\mathrm{n})$, numerical frequency $(\mathrm{N} \%)$, weight in grams $(\mathrm{W})$, weight frequency (W\%) relative importance index (IRI), relative importance index in percentage (IRI\%) and order of importance (OI-IRI) of the food items in diet of Hypanus marianae off Pernambuco coast, from July 2013 to October 2016.

\begin{tabular}{|c|c|c|c|c|c|c|c|c|c|}
\hline Prey's item & $\mathrm{O}$ & $\% \mathrm{FO}$ & $\mathrm{n}$ & $\% \mathrm{~N}$ & $\mathrm{~W}$ & $\% \mathrm{~W}$ & IRI & \%IRI & OI-IRI \\
\hline Phylum Sipuncula & 8 & 10.39 & 13 & 1.41 & 3.79 & 3.32 & 49.19 & 0.87 & 11 \\
\hline \multicolumn{10}{|l|}{ Phylum Annelida } \\
\hline Class Polychaeta & 49 & 63.64 & 85 & 9.25 & 30.69 & 26.88 & 2299.30 & 40.65 & 1 \\
\hline \multicolumn{10}{|l|}{ Phylum Arthropoda } \\
\hline \multicolumn{10}{|l|}{ Class Crustacea } \\
\hline \multicolumn{10}{|l|}{ Order Decapoda } \\
\hline \multicolumn{10}{|l|}{ Suborder Pleocyemata } \\
\hline Family Palinuridae & 2 & 2.60 & 2 & 0.22 & 0.06 & 0.05 & 0.69 & 0.01 & 19 \\
\hline \multicolumn{10}{|l|}{ Family Scillaridae } \\
\hline Scyllarides sp. & 1 & 1.30 & 3 & 0.33 & 0.27 & 0.24 & 0.73 & 0.01 & 19 \\
\hline Suborder Dendrobranchiata & 29 & 37.66 & 113 & 12.30 & 3.43 & 3.00 & 576.09 & 10.18 & 3 \\
\hline \multicolumn{10}{|l|}{ Family Penaeidae } \\
\hline Rimapenaeus constrictus & 7 & 9.09 & 23 & 2.50 & 3.73 & 3.27 & 52.48 & 0.93 & 10 \\
\hline Sicyonia parri & 2 & 2.60 & 4 & 0.44 & 0.12 & 0.11 & 1.41 & 0.02 & 18 \\
\hline Pleoticus mиelleri & 3 & 3.90 & 4 & 0.44 & 1.78 & 1.56 & 7.75 & 0.14 & 15 \\
\hline \multicolumn{10}{|l|}{ Family Caridae } \\
\hline Leptochaela serratorbita & 30 & 38.96 & 340 & 37.00 & 8.08 & 7.07 & 1717.00 & 30.35 & 2 \\
\hline Family Sergestoidae & 3 & 3.90 & 95 & 10.34 & 0.54 & 0.47 & 42.12 & 0.74 & 13 \\
\hline Acetes americanus & 1 & 1.30 & 1 & 0.11 & 0.01 & 0.01 & 0.16 & $<0.01$ & 20 \\
\hline Suborder Brachyura & 8 & 10.39 & 10 & 1.09 & 5.79 & 5.07 & 63.97 & 1.13 & 9 \\
\hline \multicolumn{10}{|l|}{ Family Portunidae } \\
\hline Callinectes sp. & 14 & 18.18 & 20 & 2.18 & 9.45 & 8.27 & 190.01 & 3.36 & 6 \\
\hline Callinectes exasperatus & 2 & 2.60 & 5 & 0.54 & 2.96 & 2.60 & 8.16 & 0.14 & 15 \\
\hline Microphrys bicornutus & 1 & 1.30 & 1 & 0.11 & 1.47 & 1.29 & 1.82 & 0.03 & 17 \\
\hline \multicolumn{10}{|l|}{ Family Upogebiidae } \\
\hline Upogebia sp. & 6 & 7.79 & 7 & 0.76 & 0.98 & 0.86 & 12.63 & 0.22 & 14 \\
\hline Order Amphipoda & 3 & 3.90 & 10 & 1.09 & 0.10 & 0.09 & 4.58 & 0.08 & 16 \\
\hline Order Isopoda & 16 & 20.78 & 96 & 10.45 & 1.09 & 0.95 & 236.82 & 4.19 & 4 \\
\hline Class Cephalocarida & 1 & 1.30 & 1 & 0.11 & 0.01 & 0.01 & 0.15 & $<0.01$ & 20 \\
\hline Order Stomatopoda & 11 & 14.29 & 24 & 2.61 & 2.45 & 2.15 & 67.98 & 1.20 & 8 \\
\hline \multicolumn{10}{|l|}{ Family Squillidae } \\
\hline Meiosquilla schmitti & 12 & 15.58 & 50 & 5.44 & 8.53 & 7.47 & 201.19 & 3.56 & 5 \\
\hline \multicolumn{10}{|l|}{ Phylum Chordata } \\
\hline \multicolumn{10}{|l|}{ Class Actinopterygii } \\
\hline Teleost & 7 & 9.09 & 7 & 0.76 & 8.48 & 7.42 & 74.40 & 1.32 & 7 \\
\hline \multicolumn{10}{|l|}{ Family Holocentridae } \\
\hline Holocentrus adscensionis & 2 & 2.60 & 5 & 0.54 & 20.38 & 17.85 & 47.77 & 0.84 & 12 \\
\hline Total & 77 & 100 & 919 & 100 & 114.18 & 100 & 5656.40 & 100 & \\
\hline
\end{tabular}

the Brazilian coast inhabiting the marine substrate also feeds mainly on polychaetes and crustaceans. The species Hypanus americanus (Aguiar, 2010), Hypanus guttatus (Silva et al., 2001; Carvalho-Neta \& de Almeida, 2002; Gianeti, 2011), Urotrygon microphtalmum (Santander-Neto, 2015), Rioraja agassizii, Zapteryx brevirostris and Rhinoptera bonasus (Bornatowski et al., 2014) have shrimp or polychaetes as main groups of prey of the diet, similar to $H$. marianae.
According to Costa et al. (2015), shrimp of the suborder Dendrobranchiata (29.0\% of IRI) and the class of Polychaeta (12.2\% of IRI) were the second and the fourth most important items in the diet of $H$. marianae. However, Shibuya \& Rosa (2011) indicated shrimp as the main item, with $70.57 \%$ of IRI, whereas polychaetes were only $0.76 \%$ of IRI. Overall, the decapod crustaceans tended to be one of the most important prey items for the stingrays (Bornatowski et al., 2010, 2014; Pardo et al., 2015) because shrimp and 




Figure 3. Non-metric multidimensional scaling analysis (nMDS) of Hypanus marianae based on the weight of the diet items: females distribution polygon (dashed line), males distribution polygon (solid line), young of the year (square), immature (circle) mature (triangle). AMPH: Amphipoda; DECA: Decapoda; OCRUS: Other Crustacea; POLLY: Polychaete; INVERT: Invertebrates; FISH: fishes; YOY: young of the year.

polychaetes are abundant prey for coralline stingrays (O'Shea et al., 2013).

The specialized diet of $H$. marianae based on shrimp and polychaetes can be due to the small mouth aperture, which limits prey size (Tilley et al., 2013). This consideration also fits for Zapteryx brevirostris, which feed on the same prey (Bornatowski et al., 2014).

It is known that some batoids capture and process their prey through movements of the oral cavity, allowing strict internal orientation of the water flow (Dean et al., 2005). As observed by Shibuya \& Rosa (2011), stomach contents of $H$. marianae suggest similar foraging behavior due to the presence of many preys from the same group, presenting a similar degree of digestion as well as the occurrence of sediments.

Furthermore, ANOSIM revealed no significant differences in diet between the sexes (Global $\mathrm{R}=0.04$; $P=0.09$ ), similar to Hypanus longus (López-García et al., 2012); Urotrygon rogersi (Navia et al., 2011); Dasyatis chrysonota (Ebert \& Cowley, 2003); Bathyraja brachyurops (Belleggia et al., 2008) and Bathyraja magellanica (Barbini et al., 2010). Nonetheless, nMDS showed an overlap of prey categories used by males and females (Fig. 3). The different contributions of the same food category for male and female diets (Polychaeta and Decapod Crustacea) (Table 2) can reflect sexual segregation for this species (Yokota \& Lessa, 2006). Thus, teleostean fish in the adult female diet of $H$. marianae may be related to the use of different habitats. Thus, corroborating the observation by Yokota \& Lessa
(2007) and Costa et al. (2015) about ontogenetic and sexual segregation for $H$. marianae, which is also reinforced by Motta et al. (2009), who reported fishes from Scaridae family in the contents of a pregnant female captured in northern Brazil (Maranhão State).

Teleost fish are bigger and faster than shrimp, which explains the presence of this item almost exclusively in the adult diet - something that is related to their higher predation capacity (Sisneros \& Tricas, 2002a) and their larger mouth width enabling the catch of larger prey. Size-related shifts in the diet for $N$. kuhlii (Pardo et al., 2015) were reported with decreasing importance of polychaetes and the increased importance of carid shrimp and teleost fishes. Although there are no significant differences in the diet among the sexual development stages for $H$. marianae (Global $\mathrm{R}=0.02$; $P=0.23$; Fig. 3), the SIMPER showed an ontogenetic change in the contribution of each item in the diet of the stingray (Table 2). Also, a diet shift in batoids during ontogeny is widely known (Sisneros \& Tricas, 2002b; Kyne et al., 2008; Jacobsen \& Bennett, 2011; Vaudo \& Heithaus, 2011; Yick et al., 2011; López-García et al., 2012; Ruocco \& Lucifora, 2016).

Some factors related to diet shift are habitat change, an increase in the size of prey relative to an increase in the size of the predator, differences in movement patterns and an improvement in the ability to capture prey (Wetherbee \& Cortés, 2004; Aguiar \& Valentim, 2010; Grubbs, 2010).

Costa et al. (2015) suggest that the use of diverse habitats may result in different prey availability in each area, and this may explain the SIMPER results. In this study, neonates are found on the beaches, whereas larger individuals are found at greater depths, similar to reports on the species in other areas (Yokota \& Lessa, 2007).

The trophic level estimated for $H$. marianae based on stomach content analysis (3.66) and $\delta^{15} \mathrm{~N}$ value (3.29) places the species at an intermediate level of the food chain, as a mesopredator (Cortés, 1997; Ebert \& Bizarro, 2007). Both the trophic levels (obtained through SCA and SIA) presented values expected for the Dasyatidae family, ranging between 3.16 and 4.08 (Jacobsen \& Bennett, 2013).

Hypanus marianae in Brazil occupies a trophic level $(\mathrm{TL}=3.6)$ similar to $H$. americanus $(\mathrm{TL}=3.52)$ in the Caribbean (Tilley et al., 2013), Urotrygon aspidura $(\mathrm{TL}=3.7)$ and $U$. rogersi $(\mathrm{TL}=3.5)$ in Colombia (Navia et al., 2016), N. kuhlii $(\mathrm{TL}=3.58)$, Neotrygon annotata $(\mathrm{TL}=3.57)$, and Neotrygon picta $(\mathrm{TL}=3.55)$ in Australia (Jacobsen \& Bennett, 2012), Rhinoptera bonasus $(\mathrm{TL}=3.4)$ in Brazil (Bornatowski et al., 2014) and Myliobatis goodei $(\mathrm{TL}=3.2)$ in Patagonia (Molina \& Cazorla, 2015), because their diet is based mainly on invertebrates. 
Table 2. Items contributing to the diet differentiation between sexes and among the sexual development stages of Hypanus marianae according to Similarity Percentage analysis (SIMPER). YOY: young of the year.

\begin{tabular}{lcccccc}
\hline \multirow{2}{*}{ Sample number } & \multicolumn{2}{c}{ Sex } & & \multicolumn{3}{c}{ Sexual development stages } \\
\cline { 2 - 3 } \cline { 5 - 7 } & Female $(\%)$ & Male $(\%)$ & & YOY $(\%)$ & Immature (\%) & Mature (\%) \\
\cline { 2 - 3 } Decapods & 39 & 38 & & 7 & 42 & 28 \\
Polychaetes & 73.01 & 37.98 & & 70.68 & 69.5 & 30.47 \\
Fishes & 21.36 & 57.01 & & 17.09 & 25.86 & 62.79 \\
Amphipods & 3.93 & 0.02 & & - & 0.01 & 5.46 \\
Other crustaceans & 0.62 & 0.83 & & 12.23 & 0.95 & - \\
Sipuncula & 0.59 & 3.53 & & - & 2.66 & 0.99 \\
\hline
\end{tabular}

Table 3. Mean values for $\delta^{13} \mathrm{C}$ and $\delta^{15} \mathrm{~N} \pm \mathrm{SD}$ (standard deviation) and estimated trophic level through stomach content analysis (TL SCA) and stable isotope analysis $\left(\mathrm{TL} \delta^{15} \mathrm{~N}\right)$ for Hypanus marianae. *Rosa \& Moura (1997).

\begin{tabular}{lccccccc}
\hline & Sample number & Mean $\delta^{13} \mathrm{C}$ & SD & Mean $\delta^{15} \mathrm{~N}$ & SD & TL SCA & TL $\delta^{15} \mathrm{~N}$ \\
\hline Sparisoma axillari & 2 & -17.11 & 1.80 & 9.75 & 0.16 & $2.0^{*}$ & - \\
Hypanus marianae & 8 & -14.06 & 0.87 & 11.68 & 0.92 & 3.66 & 3.29 \\
\hline
\end{tabular}

Similarly, to other Myliobatiformes mesopredators (O'Gorman \& Emmerson, 2009), H. marianae can play an important ecological role in the environment, controlling the populations of reef invertebrates used as prey, and being food source of other species (Vaudo \& Heithaus, 2011) such as reef sharks (Costa et al., 2015) and other stingrays such as $\mathrm{H}$. americanus (BrancoNunes et al., 2016). Linking top predators to lower trophic levels, this species can promote the energy flow of the ecosystems it inhabits.

\section{ACKNOWLEDGMENTS}

We thank Dr. Luiz Martinelli (Universidade de São Paulo - CENA-ESALQ) and Dr. Nigel Hussey (University of Windsor-GLIER) for the stable isotope analyses. Thanks also to Esteban Vidal and Aldenise Oliveira (Centro de Tecnologias Estratégicas do Nordeste CETENE) for lyophilizing the samples. This study was supported by the Conselho Nacional de Desenvolvimento Científico e Tecnológico-CNPq through APQ 483224/2013-8 and supplied a Productivity Research Grant to R.L. (PQ 306672/2015). Fundação de Amparo à Ciência e Tecnologia de Pernambuco-FACEPE supplied Scholarships to A.P. (IBPG-0658-2.04/14) and M.L. (Post Doctoral DCR 0086-5.06/12).

\section{REFERENCES}

Aguiar, A.A. \& Valentin, J.L. 2010. Biologia e ecologia alimentar de elasmobrânquios (Chondrichthyes: Elasmobranchii): uma revisão dos métodos e do estado da arte no Brasil. Oecologia Australis, 14: 464-489.
Albo-Puigserver, M., Navarro, J., Coll, M., Aguzzi, J., Cardona, L. \& Sáez-Liante, R. 2015. Feeding ecology and trophic position of three sympatric demersal chondrichthyans in the northwestern Mediterranean. Marine Ecology Progress Series, 524: 255-268.

Aschliman, N.C., Claeson, K.M. \& McEachran, J.D. 2012. Phylogeny of batoidea. In: Carrier, J.C., Musick, J.A. \& Heithaus, M.R. (Eds.). Biology of sharks and their relatives. University Press, Bloomington, pp. 5794.

Barbini, S.A., Scenna, L.B., Figueroa, D.E., Cousseau, M.B. \& De Astarloa, J.M.D. 2010. Feeding habits of the Magellan skate: effects of sex, maturity stage, and body size on diet. Hydrobiologia, 641: 275-286.

Belleggia, M., Mabragaña, E., Figueroa, D.E., Scenna, L.B., Barbini, S.A. \& Díaz de Astarloa, J.M. 2008. Food habits of the broad nose skate, Bathyraja brachyurops (Chondrichthyes, Rajidae), in the southwest Atlantic. Scientia Marina, 72: 701-710.

Bender, M.G., Floeter, S.R., Mayer, F.P., Vila-Nova, D.A., Longo, G.O., Hanazaki, N., Carvalho-Filho, A.E. \& Ferreira, C.E.L. 2013. Biological attributes and major threats as predictors of the vulnerability of species: a case study with Brazilian reef fishes. Oryx, 47: 259-265.

Bigelow, H.B. \& Schroeder, W.C. 1953. Sawfishes, guitarfishes, skates, and rays. Fishes of the western north Atlantic. Yale University Press, Connecticut.

Bornatowski, H., Robert, M.D.C. \& Costa, L. 2010. Feeding of guitarfish Rhinobatos percellens (Walbaum, 1972) (Elasmobranchii, Rhinobatidae), the target of artisanal fishery in southern Brazil. Brazilian Journal of Oceanography, 58: 45-52. 
Bornatowski, H., Wosnick, N., do Carmo, W.P.D., Corrêa, M.F.M. \& Abilhoa, V. 2014. Feeding comparisons of four batoids (Elasmobranchii) in coastal waters of southern Brazil. Journal of the Marine Biological Association of the United Kingdom, 94: 1491-1499.

Branco-Nunes, I.S.L., Albuquerque, F.V., Nunes, D.M., Oliveira, P.G.V. \& Hazin, F.H.V. 2016. First record of predation between Dasyatis species. Journal of Fish Biology, 4: 2178-2181.

Do Carmo, W.P., Bornatowski, H., Oliveira, E.C. \& Fávaro, L.L. 2015. Diet of the chola guitarfish, Rhinobatos percellens (Rhinobatidae), in the Paranaguá Estuarine complex. Anais da Academia Brasileira de Ciências, 87: 721-731.

Carvalho-Neta, R.N.F.C. \& de Almeida, Z.D. 2002. Aspectos alimentares de Dasyatis guttata (Elasmobranchii, Dasyatidae) na costa maranhense. Boletim do Laboratório de Hidrobiologia, 14: 77-98.

Clarke K.R. \& Gorley, R.N. 2006. PRIMER v6: user manual. PRIMER-E Ltd., Plymouth.

Cortés, E.A. 1997. A critical review of methods of studying fish feeding based on analysis of stomach contents: application to elasmobranch fishes. Canadian Journal of Fisheries and Aquatic Science, 54: 726-738.

Cortés, E. 1999. Standardized diet compositions and trophic levels of sharks. ICES Journal of Marine Science, 56: 707-717.

Costa, T.L., Pennino, M.G. \& Mendes, L. 2017. Identifying ecological barriers in the marine environment: the case study of Dasyatis marianae. Marine Environmental Research, 125: 1-9.

Costa, T.L.A., Thayer, J.A. \& Mendes, L.F. 2015. Population characteristics, habitat and diet of a recently discovered stingray Dasyatis marianae: implications for conservation. Journal of Fish Biology, 86: 527-543.

Dean, M.N., Wilga, C.D. \& Summers, A.P. 2005. Eating without hands or tongue: specialization, elaboration, and the evolution of prey processing mechanisms in cartilaginous fishes. Biology Letters, 357-361.

Ebert, D.A. \& Bizzarro J.J. 2007. Standardized diet compositions and trophic levels of skates (Chondrichthyes: Rajiformes: Rajoidei). Environmental Biology of Fishes, 80: 221-237.

Ebert, D.A. \& Compagno, L.J. 2007. Biodiversity and systematics of skates (Chondrichthyes: Rajiformes: Rajoidei). Environmental Biology of Fishes, 80: 111124.

Ebert, D.A. \& Cowley, P.D. 2003. Diet, feeding behavior, and habitat utilization of the blue stingray Dasyatis chrysonota (Smith, 1828) in South African waters. Marine and Freshwater Research, 54: 957-965.
Galván, D.E., Jañez, J. \& Irigoyen, A. 2016. Estimating tissue-specific discrimination factors and turnover rates of stable isotopes of nitrogen and carbon in the small nose fanskate Sympterygia bonapartii (Rajidae). Journal of Fish Biology, 89: 1258-1270.

Gianeti, M.D. 2011. Reprodução, alimentação, idade e crescimento de Dasyatis guttata (Bloch \& Schneider, 1801) (Elasmobranchii, Dasyatidae) na região de caiçara do norte-RN. Unpublished Thesis, Universidade de São Paulo, São Paulo, 131 pp. [http:// www.teses.usp.br/teses/disponiveis/21/21131/tde-190 42012-145635/en.php]. Reviewed: August 13, 2018.

Gilliam, D. \& Sullivan, K.M. 1993. Diet and feeding habits of the southern stingray Dasyatis americana in the Central Bahamas. Bulletin of Marine Science, 52: 1007-1013.

Gomes, U.L., Rosa, R.S. \& Gadig, O.B.F. 2000. Dasyatis macrophthalma sp. n.: a new species of stingray (Chondrichthyes: Dasyatidae) from the southwestern Atlantic. Copeia, 2000(2): 510-515.

Grubbs, R.D. 2010. Ontogenetic shifts in movements and habitat use. In: Carrier, J.C., Musick, J.A. \& Heithaus, M.R. (Eds.). Sharks and their relatives II: biodiversity, adaptive physiology, and conservation. CRC Press, Boca Raton, pp. 319-350.

Grubbs, R.D., Carlson, J.K., Romine, J.G., Curtis, T.H., McElroy, W.D., McCandless, C.T. \& Musick, J.A. 2016. Critical assessment and ramifications of a purported marine trophic cascade. Scientific Reports, 6: 20970.

Heithaus, M.R., Frid, A., Wirsing, A.J. \& Worm, B. 2008. Predicting ecological consequences of marine top predator declines. Trends in Ecology \& Evolution, 23: 202-210.

Hussey, N.E., MacNeil, M.A., McMeans, B.C., Olin, J.A., Dudley, S.F., Cliff, G. \& Fisk, A.T. 2014. Rescaling the trophic structure of marine food webs. Ecology Letters, 17: 239-250.

International Council for the Exploration of the Sea (ICES). 2012. Report of the workshop on sexual maturity staging of elasmobranchs (WKMSEL). ICES WKMSEL Report, Lisbon, 113 pp.

Jacobsen, I.P. \& Bennett, M.B. 2011. Life history of the black-spotted whip ray Himantura astra. Journal of Fish Biology, 78: 1249-1268.

Jacobsen, I.P. \& Bennett, M.B. 2012. Feeding ecology and dietary comparisons among three sympatric Neotrygon (Myliobatoidei: Dasyatidae) species. Journal of Fish Biology, 80: 1580-1594.

Jacobsen, I.P. \& Bennett, M.B. 2013. A comparative analysis of feeding and trophic level ecology in 
stingrays (Rajiformes; Myliobatoidei) and electric rays (Rajiformes: Torpedinoidei). Plos One, 8: e71348.

Kim, S.L. \& Koch, P.L. 2012. Methods to collect, preserve, and prepare elasmobranch tissues for stable isotope analysis. Environmental Biology of Fishes, 95: 53-63.

Krebs, C.J. 1999. Ecological methodology. AddisonWesley, Menlo Park.

Kyne, P.M., Courtney, A.J. \& Bennett, M.B. 2008. Aspects of reproduction and diet of the Australian endemic skate Dipturus polyommata (Ogilby) (Elasmobranchii: Rajidae), bycatch of a commercial prawn trawl fishery. Journal of Fish Biology, 72: 6177.

López, N., Navarro, J., Barría, C., Albo-Puigserver, M., Coll, M. \& Palomera, I. 2016. Feeding ecology of two demersal opportunistic predators coexisting in the northwestern Mediterranean Sea. Estuarine, Coastal and Shelf Science, 175: 15-23.

López-García, J., Navia, A.F., Mejía-Falla, P.A. \& Rubio, E.A. 2012. Feeding habits and trophic ecology of Dasyatis longa (Elasmobranchii: Myliobatiformes): sexual, temporal, and ontogenetic effects. Journal of Fish Biology, 80: 1563-1579.

Madigan, D.J., Brooks, E.J., Bond, M.E., Gelsleichter, J., Howey, L.A., Abercrombie, D.L., Broocks, A. \& Chapman, D.D. 2015. Diet shift and site-fidelity of oceanic whitetip sharks Carcharhinus longimanus along the Great Bahama Bank. Marine Ecology Progress Series, 529: 185-197.

Magnusson, W.E., Lima, A.P., Alves da Silva, W. \& Carmozina de Araújo, M. 2003. Use of geometric forms to estimate the volume of invertebrates in ecological studies of dietary overlap. Copeia, 2003(1): 13-19.

Marshall, A.D., Kyne, P.M. \& Bennett, M.B. 2008. Comparing the diet of two sympatric urolophid elasmobranchs (Trygonoptera testacea Müller \& Henle and Urolophus kapalensis Yearsley \& Last): evidence of ontogenetic shifts and possible resource partitioning. Journal of Fish Biology, 72: 883-898.

McEachran, J.D. \& Carvalho, M.R. 2002. Dasyatidae. In: Carpenter, K.E. (Ed.). The living marine resources of the western central Atlantic. Vol. 1: introduction, mollusks, crustaceans, hagfishes, sharks, batoid fishes, and chimaeras. FAO species identification guide for fisheries purposes and American Society of Ichthyologists and Herpetologists Special Publication 5, Rome.

Molina, J.M. \& Cazorla, A.L. 2015. Biology of Myliobatis goodei (Springer, 1939), a widely distributed eagle ray, caught in northern Patagonia. Journal of Sea Research, 95: 106-114.

Motta, F.S., Moura, R.L., Francini-Filho, R.B. \& Namora, R.C. 2009. Notas sobre a biologia reprodutiva e alimentar de elasmobrânquios no Parque Estadual Marinho Parcel Manoel Luís, Maranhão - Brasil. PanAmerican Journal of Aquatic Sciences, 4: 593-598.

Myers, R.A., Baum, J.K., Shepherd, T.D., Powers, S.P. \& Peterson, C.H. 2007. Cascading effects of the loss of apex predatory sharks from a coastal ocean. Science, 315: 1846-1850.

Navia, A.F., Mejía-Falla, P.A. \& Giraldo, A. 2007. Feeding ecology of elasmobranch fishes in coastal waters of the Colombian eastern tropical Pacific. BMC Ecology, 7: 8-18.

Navia, A.F., Mejía-Falla, P.A. \& Hleap, J.S. 2016. Zoogeography of elasmobranchs in the Colombian Pacific Ocean and the Caribbean Sea. Neotropical Ichthyology, 1: 14.

Navia, A.F., Torres, A., Mejía-Falla, P.A. \& Giraldo, A. 2011. Sexual, ontogenetic, temporal, and spatial effects on the diet of Urotrygon rogersi (Elasmobranchii: Myliobatiformes). Journal of Fish Biology, 78, 1213-1224.

O'Gorman, E.J. \& Emmerson, M.C. 2009. Perturbations to trophic interactions and the stability of complex food webs. Proceedings of the National Academy of Science, 106: 13393-13398.

O'Shea, O.R., Thums, M., Van Keulen, M., Kempster, R.M. \& Meekan, M.G. 2013. Dietary partitioning by five sympatric species of stingray (Dasyatidae) on coral reefs. Journal of Fish Biology, 82: 1805-1820.

Pardo, S.A., Burgess, K.B., Teixeira, D. \& Bennett, M.B. 2015. Local-scale resource partitioning by stingrays on an intertidal flat. Marine Ecology Progress Series, 533: 205-218.

Peterson, B.J. \& Fry, B. 1987. Stable isotopes in ecosystem studies. Annual Review of Ecology, Evolution, and Systematics, 18: 293-320.

Pinkas, L., Oliphant, M.S. \& Iverson, I.L.K. 1971. Food habits of albacore, bluefin tuna, and bonito in Californian waters. California Fish and Game, 152: $105 \mathrm{pp}$.

Post, D.M. 2002. Using stable isotopes to estimate trophic position: models, methods, and assumptions. Ecology, 83: 703-718.

Rocchi, M., Scotti, M., Micheli, F. \& Bodini, A. 2017. Key species and impact of fishery through food web analysis: a case study from Baja California Sur, Mexico. Journal of Marine Systematics, 165: 92-102.

Rosa, R.S. \& Moura, R.L. 1997. Visual assessment of reef fish community structure in the Atol Das Rocas 
Biological Reserve, off northeastern Brazil. Proceedings of the 8th International Coral Reef Symposium, 1: 983-986.

Rosa, R. \& Furtado, M. 2016. Hypanus guttatus. The IUCN red list of threatened species. [http://dx.doi.org/10.2305/IUCN.UK.20163.RLTS.T44592A104125099.en.]. Reviewed: June 13, 2017.

Rosa, R.S. \& Gadig, O.B.F. 2014. Conhecimento da diversidade dos Chondrichthyes marinhos no Brasil: a contribuição de José Lima de Figueiredo. Arquivos de Zoologia, 45: 89-104.

Ruocco, N. \& Lucifora, L. 2016. Ecological singularity of temperate mesopredatory myliobatoid rays (Chondrichthyes: Myliobatiformes). Marine and Freshwater Research, 68: 1098-1111.

Santander-Neto, J.S. 2015. Dinâmica populacional da raia Urotrygon microphthalmum Delsman, 1941 no nordeste do Brasil. Unpublished Thesis. Universidade Federal de Pernambuco, Recife, 143p. [https:// repositorio.ufpe.br/handle/123456789/13980]. Reviewed: August 13, 2018.

Santos, H.R.S. \& Carvalho, M.R. 2007. Application of the "Principle of the first reviser" to determine the correct spelling for a recently described stingray species from the western South Atlantic Ocean (Chondrichthyes, Myliobatiformes, Dasyatidae). Archivos do Museu Nacional do Rio de Janeiro, 65: 17-18.

Shibuya, A. \& Rosa, R.S. 2011. Diet composition of Dasyatis marianae (Elasmobranchii: Dasyatidae) off Paraíba State, Brazil. Arquivos de Ciências do Mar, 44: 89-92.

Silva, G.B.D., Viana, M.S.R. \& Furtado-Neto, M.A.A. 2001. Morfologia e alimentação da raia Dasyatis guttata (Chondrichthyes:Dasyatidae) na Enseada do Mucuripe, Fortaleza, Ceará. Arquivos de Ciências do Mar, 34: 67-75.

Sisneros, J.A. \& Tricas, T.C. 2002a. Neuroethology and life history adaptations of the elasmobranch electric sense. Journal of Physiology, 96: 379-389.

Received: 13 December 2018; Accepted: 1 August 2019
Sisneros, J.A. \& Tricas, T.C. 2002b. Ontogenetic changes in the response properties of the peripheral electrosensory system in the Atlantic stingray (Dasyatis sabina). Brain, Behavior and Evolution, 59: 130-140.

Tilley, A., López-Angarita, J. \& Turner, J.R. 2013. Diet reconstruction and resource partitioning of a Caribbean marine mesopredator using stable isotope bayesian modelling. Plos One, 8: e79560.

Vaudo, J.J. \& Heithaus, M.R. 2011. Dietary niche overlap in a nearshore elasmobranch mesopredator community. Marine Ecology Progress Series, 425: 247-260.

Weigmann, S. 2016. Annotated checklist of the living sharks, batoids and chimaeras (Chondrichthyes) of the world, with a focus on biogeographical diversity. Journal of Fish Biology, 88: 837-1037.

Wetherbee, B.M. \& Cortés, E. 2004. Food consumption and feeding habits. In: Carrier, J.C., Musick, J.A. \& Heithaus, M.R. (Eds.). Biology of sharks and their relatives. CRC Press, Boca Raton, pp. 225-246.

Wilga, C.A., Diniz, S.E., Steele, P.R., Sudario-Cook, J., Dumont, E.R. \& Ferry, L.A. 2016. Ontogeny of feeding mechanics in smoothhound sharks: morphology and cartilage stiffness. Integrative and Comparative Biology, 56: 442-448.

Yick, J.L., Tracey, S.R. \& White, R.W.G. 2011. Niche overlap and trophic resource partitioning of two sympatric batoids co-inhabiting an estuarine system in southeast Australia. Journal of Applied Ichthyology, 27: 1272-1277.

Yokota, L. \& Lessa, R.P. 2006. A nursery area for sharks and rays in northeastern Brazil. Environmental Biology of Fishes, 75: 349-360.

Yokota, L. \& Lessa, R.P. 2007. Reproductive biology of three ray species: Gymnura micrura (Bloch \& Schneider, 1801), Dasyatis guttata (Bloch \& Schneider, 1801) and Dasyatis marianae Gomes, Rosa \& Gadig, 2000, caught by artisanal fisheries in northeastern Brazil. Cahiers de Biologie Marine, 48: 249-257. 